\title{
Implementasi Mutu Terpadu dalam Sistem Pendidikan di Ma'had Aly
}

\author{
Oleh: Sevia Diana Safitri
}

\begin{abstract}
Abstrak
Manajemen Mutu Pendidikan adalah suatu filosofi yang sangat penting yang digunakan dalam pengembangan. Di dalam beberapa tahun terakhir ini konsep Total Quality Management telah diterapkan dalam dunia pendidikan. Banyak aplikasi telah digunakan dari segi administrasi tetapi, ada juga beberapa lembaga telah menerapkan TQM dalam pengembangan kurikulum. Di dalam jurnal ini pengertian Total Quality Management dengan penekanan pada pentingnya mengidentikasi dan menganalisis prosesnya.
\end{abstract}

\section{Pendahuluan}

Sejak tahun 1980 perkembangan mutu terpadu pada mulanya sebagai suatu sistem perkembangan di Amerika Serikat. Dikarenakan apa? Pada saat itu masyarakat disana kurang berpartisipasi terhadap perkembangan mutu pendiidikan terutama masyarakat bisnis. Akan tetapi, dari beberapa mereka merupakan pemegang kunci dalam pengenalan dan pengembangan konsep mutu terpadu.Pada suatu lembaga sangatlah penting terhadap kualitas manajemen yang perlu diutamakan bagi sebuah lembaga. Oleh kerenanya, kualitas manajemen menjadi titik utama atau menjadi suatu tujuan organisasi yang bertujuan untuk meningkatkan kualtas yang telah diterapkan pada produk, pelayanan, dan lain-lain. Dari berbagai upaya untuk meningkatkan mutu atau kualitas pendidikan yang begitu tinggi dan dilaksanakan secara bertahap dan berkelanjutan yang disusun dengan rapi. ${ }^{1}$ Diantara strategi

Achmad Supriyanto, Implentasi Total Quality Management dalam Sistem Manajemen Mutu Pembelajaran di Institusi Pendidikan, No.1 februari 2011,Th xxx 
pengembanganya iyalah dilakukan dengan menerapkan peningkatan kualitas pendidikan pada masa yang akan datang. Dengan kata lain bisa dikatakan pula dengan kata Total Qualty Management. TQM sendiri mempunyai arti yakni sebagai pendekatan di dalam menjalankan usaha untuk memaksimalkan daya saing suatu organisasi melalui jasa, manusia, proses, dan lingkungannya (Tjiptono dan Diana, 2004). TQM disini bertujuan untuk mengadakan perbaikan secara berkelanjutan dalam rangka meningkatkan persaingan dalam era global yang akan mendatang.

Beberapa indikasi keberhasilan suatu lembaga pendidikan yang mempraktekan TQM dengan melalui: 1). Komitmen yang tinggi dari seluruh jajaran atasan sampai dengan jajaran paling rendah. 2). Hubungan relasi antara atasan dengan bawahan berjalan dengan lancar. 3). Motivasi dan disiplin yang begitu tinggi. Ada lima pilar keberhasilan pengimplentasian TQM pada suatu lembaga pendidikan iyalah berupa: produk, proses, organisasi, kepemimpinan, dan komitmen (Creech,2000:4).

Perusahaaan Jepang yang telah sukses secara umum karena memasarkan produk atau jasa yang sangat berkulitas. Perusahaan ataupun lembaga yang ingin mengikuti perlombaan untuk meraih manfaat tidak ada jalan lain kecuali harus menerapkan Total Quality Management. Di jepang TQM diringkas menjadi empat cara sebagai berikut:

a Kaizen: difokuskan pada proses berkelanjutan sehingga prsoses yang terjadi pada organisasi menjadi dapat dilihat, dilakukan secara berulangulang, dan dapat diukur.

b Atarimae Hinshitsu : berfokis pada efek intangible pada proses dan optimasi dari efek tersebut.

c Kansei : meneliti cara penggunaan produk oleh konsumen untuk penigkatan mutu kualitas produk itu sendiri.

d Miryokuteki Hinshitsu : manajemen taktis yang digunakan dalam produk yang siap untuk diperdagangkan 
Jadi, dari empat langkah yang diciptakan oleh masyarakat jepang yang telah disebutkan di atas. Maka oleh karna itu, penerpan atau pengimpetasikan TQM perlu mencontohkan negara Jepang itu sendiri dengan hal tersebut tujuan yang akan kita rencanakan akan terpenuhi secara berlangsung. Ada beberapa faktor pendorong dan penghalang dalam implementasi TQM di asrama Ma'had Aly itu sendiri mencangkup : dukungan yang efektif dan efesien, persatuan dan kesatuan antara pengajar dengan pelajar, target yang sesuai dengan tujuannya,dan akan dirubah terus-menerus, komunikasi dan pendekatan yang diorganisir. Sedangkan penghalang dalam implementasi TQM adalah penolakan terhadap pengajar dan pelajar, penolakan dari manajemen menengah, dan dukungan dari pihak luar, tidak terlaksana planning yang akan dilaksanakan pelaksana yang buruk, waktu, anggaran biaya, sumber daya terbatas, dan kelemahan dan politik organisasi. Ada 15 respondet tiga aspek yaitu : perumusan tujuan peningkatan mutu, penerapan prinsip-prinsip TQM, komponen pendukung TQM. Tujuan TQM dalam pembelajaran adalah untuk meningkatkan kualitas di asrama Ma'had Aly yang sudah dianggap jelas dan perlu dilakukan perbaikan ketika ditemukan sesuatu yang belum sesuai.

Rumusan tujuan TQM ada sedikit mengalami perbaikan. Penerapan prinsip-prinsip TQM yang mencakup pemfokusan pada pelajar, perbaikan atau bisa disebut dengan remidi, perbaikan pada proses, dan pelibatan pelajar terhadap kegiatan kegiatan belajar mengajar. ${ }^{2}$ Proses kegiatan belajar mengajar yang sudah diterapkan pada asrama Ma'had Aly tersebut merupakan proses yang dimana hubungan dengan pelajar menggunakan sistem sorogan. Kurikulum Ma'had Aly lebih dominan pada pengajaran ilmu-ilmu keagamaan, walaupun pada sebagian yang lain ada juga yang memasukkan ilmu-ilmu umum seperti sosiologi, antropologi, dan filsafat dalam kurikulumnya. Dalam penyusunannya kurikulum Ma'had Aaly disesuaikan berdasarkan pendekatan disipliner atau konsentrasi fiqh, ushul fiqh, tafsir, hadist, ilmu hadist, tasawuf, balaghoh, faroid, falak dan lain sebagainya dengan mencampurkan penggunaan

\footnotetext{
2 Hasan Baharun, Pengembangan Kurikulum Teori \& Praktik, (Probolinggo: Pustaka Nuria 2017) hal:343
} 
kitab-kitab tingkat tinggi dalam tradisi pendidikan dalam versi pesantren. Tidak hanya kitabkitab tempo dulu yang diterapkan ada asrama Ma'had Aly akan tetapi kitab-kitab temporer yang dianggap layak.

Dalam proses pembelajarannya pada asrama Ma'had Aly menggunakan metode pengajaran yang sifatnya memberi kesempatan terhadap pelajar atau peserta didik untuk berapresiasi sesuai dengan kemauannya sendiri. Contoh metode ini seperti metode diskusi, seminar, dan penulisan laporan kepustakaan. Pengajar Ma'had Aly lebih cenderung sebagai pembimbing dalam mengikuti kegiatan belajar mengajar yang dilaksanakan setiap saat. Dan juga sebagai fasilitator dan pengarah serta pembimbing. Oleh karena itu peserta didik dituntut untuk selalu aktif pada setiap kegiatan belajar mengajar di asrama Ma'had Aly.

Dan juga peserta didik dituntut untuk selalu berinisiatif sendiri dalam mengembangkan pemahaman-pemahaman keagamaan. Ma;had Aly ditujukan untuk mengembangkan eksitensi pusat kajian dan penelitian dalam rangka mengembangkan ilmu agama yang dibaur dengan olahan ilmu pengetahuan islam. Selain itu sarana pengabdian (khidmat) kepada umat dalam rangka mewujudkan kemuliaan islam pada orang muslimin. Pada dasarnya pendirian Ma'had Aly adalah untuk mengmbangkan studi ilmu keislamaan konsentrasi fikih, melalui khazanah kitab-kitab klasik dan kotemporer lainnya untuk melahirkan ahli agama yang bertradisi ilmiah dan amaliah salaf dengan kompetensi, menguasai ilmu keislaman, mampu memahami, serta menganalisis masalah keislaman yang urgen dan kotemporer, mampu menemukan solusi dalam bidang keahliannya sehingga menjadi pedoman bagi masyrakat.

Dukungan pihak berhubungan dengan pimpinan, pelaksana, tim khusus, dalam implementasi TQM pada saat kegiatan belajar mengajar sangat diperlukan untuk mencapai keberhasilan mutu yang diharapkan. Berdasarkan data diperoleh bahwa sesungguhnya pimpinan unit kerja dinilai baik oleh anggota dalam upaya tidak lanjut, satuan tugas pelaksana cukup mendukung kegiatan belajar mengajar penjaminan mutu, dan kekompakan tiap pengajar 
yang mendukung kegiatan penjamin mutu. Kondisi ini sangat bernilai positif agar berlangsungnya kegiatan belajar mengajar dengan baik.

\section{Sistem Penyelengaraan Program Pendidikan}

Penyelenggaraan program pendidikan di Ma;had Aly Nurul Jadid menganut sistem kredit semester yang dibagi dalam program semester ganjil dan semester genap.:

1. Semester ganjil berlangsung dari bulan September sampai dengan bulan januari.

2. Semester genap berlangsung dari bulan Februari sampai bulan Juni. Masa penyelengaraan pendidikan ditempuh selama dua tahun atau setara dengan empat semester.

3. Tingkat pendidikan adalah Diploma Dua.

Tujuan dari perkuliahan di Ma'had Aly perlu memadukan antara metode tradisional pesantren dan metode-metode perkuliahan akademik Ma'had Aly pada umumnya dengan menyatukan aspek-aspek proses pendidikan. Proses pembelajaran di Ma'had Aly sebagai sarana pembentukan kader ulama masa depan tentu memerlukan suasana yang kondusif dalam proses perkuliahan. Menciptakan suasana kondisif seperti ini proses pembelajaran pada jam-jam aktif perkuliahan, tetapi juga harus ditumbuhkan budaya ilmiah dengan mengaktifkan dan melaksankan diskusi-diskusi, Musyawarah, Muraja'ah, Muthala'ah, dan Bathsul Masail di luar jam-jam aktif perkuliahan baik dipandu oleh pembimbing maupun tidak. Hal tersebut sangat berguna sebagai forum pengayaan dan pendalaman materi mata kuliah serta penajaman daya nalar, daya analisis, dan daya kritis mahasantri. 


\section{Metode Pembelajaran}

Dalam usaha pencapaian tujuan yang ideal maka metode pembelajaran yang ditempuh dengan menggunakan tiga pendekatan:

1). Pendekatan tekstual, yaitu proses pemahaman terhadap lughawiyah, Harfiyah, dan Tarkibiyah. Hal ini ditempuh dengan dua cara yaitu bimbingan seorang pengajar dan diskusi.

2). Pendekatan kontekstual yaitu suatu kehidupan nyata yang dibawakan oleh pengajar dengan mengacu pada kitab primernya dari madzhab Syafi'i.

3). Pendekatan kritis yaitu melatih diri untuk mencoba melihat beberapa karya imam mujtahid perbandingan kitab-kitab klasik dengan kitab kotemporer.

Implemtentasi TQM di asrama Ma'had Aly sudah dijalankan tetapi belum optimal. Hal ini didukung oleh adanya penciptaan budaya kualitas pada sistem pembelajaran. Namun demikian penciptaan budaya kualitas pembelajaran tersebut membutuhkan proses panjang, perlu dilakukan secara bertahap dan berkelanjutan, serta membutuhkan sumber daya manusia dan non manusia. Total Quality Management merupakan perpaduan dari fungsi-fungsi dan proses terkait ke dalam siklus hidup produksi pada tahap-tahap yang berbeda seperti desain. Perencanaan, produksi, distribusi, dan pelayanan. Ukuran keberhasilan TQM merupakan kepuasan pelanggan dan cara mencapainya melalui desain terus menerus. TQM juga merupakan pendekatan untuk daya lentur sebuah organisasi , setiap bagian, aktivitas, dan individu pada setiap tingkat untuk mencapai kualitas TQM terkait dengan masalah strategis, pemasaran dan aspek-aspek manusia dan organisasi. Salah satu faktor yang paling berpengaruh di dalam implementasi TQM adalah pengesahan secara umum, terutama pada pimpinan Ma'had Aly tidak berusaha membuat konsep TQM diterima, itu tidak mungkin bahwa usha implementasi TQM akan 
menjadi sukses. Selain itu dibutuhkan dukungan dari setiap orang dalam rantai komando. Mulai dari mudir Ma'had Aly sampai mursyid. Akan tetapi penting juga mendapatkan pengesahan dari pelajar.

Tujuan pengembangan SDM adalah untuk memperbaiki efektivitas dan efisiensi kerja dalam melaksanakan dan mencapai sasaran programkerja organisasi yang telah ditetapkan. Pendidikan bermanfaat untuk meningkatkan keahlianteoritis, konseptual dan sikap/moral manusia, sedangkan latihan bertujuan untuk meningkatkanketrampilan teknis pelaksanaan pekerjaan tertentu serta sikap agar karyawan semakin trampildan mampu melaksanakan tanggung jawab sesuai dengan standar. Deming telah secara luas dikenal sebagai bapak TQM yang berfokus pada Customer, kapasitas, dan budaya. Pada Customer mempunyai dua macam pelanggan yaitu: pelanggan eksternal dan pelanggan internal. Untuk mencapai manajemen mutu terpadu terdapat aspek-aspek yang perlu diperhatikan:

1. Perhatikan pelanggan

2. Memilki obsesi yang tinggi terhadap mutu

3. Pendekatan ilmiah dalam pengambilan keputusan dan dalam memecahkan masalah

4. Memiliki komitmen jangka panjang

5. Membutuhkan kerja sama tim

6. Memperbaiki proses secara berkesinambungan

7. Menyelanggarakan pendidikan dan pelatihan

8. Memberikan kebebasan yang terkendali

9. Memiliki kesatuan tujuan

10. Adanya keterlibatan dan pemberdayaan karyawan

Aspek yang paling di dalam manajemen ilmiah adalah adanya pemisahan antara perencanaan dan pelaksanaan. Untuk mempertahankan mutu atau kualitas atas produk dan jasa yang 
dihasilkan dibentuklah depertemen mutu. Cara terbaik agar dapat memperbaiki kemampuan komponen-komponen tersebut secara berkesinambungan adalah dengan menerapkan peran TQM.Penerapan TQM dalam suatu perusahaan dapat memberikan beberapa manfaat utama yangpada gilirannya meningkatkan laba serta daya saing perusahaan bersangkutan.Pengembangan kualitas sumber daya manusia menurut Mangkuprawiro (2002:135) danMartoyo (2000:62) adalah suatu usaha untuk meningkatkan kemampuan teknis, kemampuanteoritis, kemampuan konseptual, peningkatan moral dan peningkatan ketrampilan teknik manusia melalui pendidikan dan pelatihan.

Tujuan pengembangan SDM adalah untuk memperbaiki efektivitas dan efisiensi kerja dalam melaksanakan dan mencapai sasaran programkerja organisasi yang telah ditetapkan. Pendidikan bermanfaat untuk meningkatkan keahlianteoritis, konseptual dan sikap/moral manusia, sedangkan latihan bertujuan untuk meningkatkanketrampilan teknis pelaksanaan pekerjaan tertentu serta sikap agar karyawan semakin trampildan mampu melaksanakan tanggung jawab sesuai dengan standar. Ciri-ciri umum atau karakteristik TQM menurut crocker 2004 adalah :

a. TQM mempunyai tujuan meningkatkan komunikasi terutama antara karyawan dengan manajemen serta mencari dan memecahkan persoalan.

b. Organisasinya terdiri dari satu orang kepala dengan beberapa orang anggota yang berasal dari satu bidang pekerjaan.

c. Partisipasi anggota yang bersifat suka rela, sedangkan partisipasi kepala kepada karyawan.

d. Dalam ruang lingkup persoalan karyawan tidak bisa memilih sendiri persoalan yang akan dibahasnya karena persoalan tidak hanya terbatas pada mutu saja melainkan mencakup produktifitas, biaya keselamatan kerja, moral, dan lingkungan serta bidang lainnya. 
e. Latihan formal dalam teknik pemecahan masalah. 


\section{DAFTAR RUJUKAN}

Baharun, Hasan. 2017. Pengembangan Kurikulum Teori \& Praktik ( Probolinggo: Pustaka Nuria)

Supriyanto Ahmad, Implentasi Total Quality Management dalam Sistem Manajemen Mutu Pembelajaran di Institusi Pendidikan, No.1 februari 2011,Th xxx

Wijaya Dafid, Implementasi Manajemen Mutu Terpadu dalamPenyelenggaraan Pendidikan di Sekolah jurnal pendidikan penabur-No.10/tahun ke-7/juni 2008

Mundiri, A. (2012). PENDIDIKAN TEKNOHUMANISTIK BERBASIS CORE ETHICAL VALUES. At-Tajdid, 1(1), 37-47.

Mundiri, A. (2015). KOMITMEN ORGANISASIONAL SUMBER DAYA MANUSIA DALAM MENINGKATKAN MUTU PENDIDIKAN PESANTREN. Pedagogik, 3(1), 88-105.

Mundiri, A. (2016). THE LEADERSHIP OF HEADMASTER IN BUILDING A WORK CULTURE BASED ON PESANTREN. In International Conference on Education and Training (pp. 1-7). Malang: Faculty of Education State University of Malang.

Mundiri, A. (2017). Organizational Culture Base On Total Quality Management In Islamic Educational Institution. ADRI International Journal Of Islamic Studies and Social Sciences, 1(1), 1-11.

Mundiri, A., \& Zahra, I. (2017). Corak Representasi Identitas Ustadz dalam Proses Transmisi Pendidikan Karakter di Pesantren. Jurnal Pendidikan Islam, Vol. 2, No, 21-35. 